\title{
Thai EFL Learners' Collocational Competence and Their Perceptions of Collocational Difficulty
}

\author{
Dentisak Dokchandra \\ Kasetsart University, Sakon Nakhon Campus, Thailand
}

\begin{abstract}
The collocational competence of undergraduate students of English at a university in northeastern Thailand and their perceptions of collocational difficulty were investigated in this study. The participants were 153 2nd-, 3rd-, and 4th-year students of English selected through a convenient sampling method and via their consents to take part in the study. The participants who were enrolled in the second term of academic year 2017 were administered a collocational competence test which comprised 35 fill-in-the-blank items with optional alternatives. They were to answer a Likert's type questionnaire of 5 rating scales (Reliability coefficient $=0.96$ ) probing their perceptions of the difficulty of collocations in parallel with each test item. The data were analyzed using descriptive statistics and One-Way ANOVA was computed to test the hypothesis. The results indicated that on the whole the participants had a 'moderate level' of collocational competence. They were not significantly different in terms of their collocational competence when it comes to their different years of studies. The participants perceived collocations as fairly difficult with the idiomatic collocations reported as being the most difficult category. The findings were discussed in relation to the theoretical difficulty of collocations and suggestions for pedagogy and further research were offered.
\end{abstract}

Index Terms - collocation, competence, difficulty, perceptions

\section{INTRODUCTION}

The ability to use proficient English in both speaking and writing is entirely the result of adequate knowledge of vocabulary, especially expressive vocabulary. And this knowledge involves no other aspects than competence of collocations which are conventionalised word combinations that are often used together in a language. Collocation is the way one word is seemingly automatically used with another word in a recurring manner. For example, in the sentence Have some toast for breakfast, the preposition for is always used with the word breakfast. If someone says with or by breakfast, it is a wrong collocation, thus sounding unnatural. However, it is not always easy for a second language learner to be able to recognize or to use a collocation, although a native speaker will immediately notice when a learner uses a word combination that is different from the conventional one (Lewis, 1997).

Thai university students, especially those who major in English, are ideally expected to perform more than satisfactorily in English, and this means they use English in a natural-sounding manner. However, research has shown that collocation is and has been problematic and difficult for Thai students, impeding their proficiency in English as a result (Mongkolchai, 2008; Sridhanyarat, 2018). Moreover, this line of research has focused on the investigation of two major strands of collocations-lexical and grammatical collocations, and seems to have concluded that Thai EFL students find lexical collocations as the most difficult, followed by grammatical collocations (e.g. Yumanee \& Phoocharoensil, 2013). Very few research works have been carried out to study the collocational competence of Thai EFL students pertaining to the category of collocations in which they show their weakness or in particular the perceptions of collocational difficulty in tandem with the reception and production of English collocations. Moreover, most research works pertaining to Thai EFL university students' collocational competence focused on a limited subcategory of collocation structures such as Verb+Noun and Adjective + Noun (e.g. Meechai \& Chumvorathayee, 2014). However, research on Thai EFL students' collocational competence and their perceptions of the collocational difficulty is still scant.

In this study, an attempt was made to investigate the collocational competence of Thai undergraduate students of English based on the three classifications of collocations-lexical collocations, grammatical collocation, and idiomatic expressions, and to juxtapose the students' perceptions of collocational difficulty with their collocational competence. The results from this study would be beneficial for explaining the phenomena of language use by the learners, preparing a language course curriculum, and for framing a policy of English learning and teaching. They would also hold a theoretical significance for second language learning and teaching, adding more literature to the existing repertoire of the related literature in this line of research. The following research questions were addressed in this study:

1. What is, holistically, the collocational competence of the students of English at KUCSC?

2. Are the second, third, and fourth-year students of English at KUCSC significantly different in terms of their competence in grammatical collocations, lexical collocations, and idiomatic expressions?

3. Are the students with different English proficiency levels significantly different in terms of their collocational competence?

4. How do the students of English at KUCSC perceive collocational difficulty? 
5. Is there a significant difference in the perceptions of collocational difficulty among the second, third, and fourthyear students of English at KUCSC?

\section{LITERATURE REVIEW}

\section{A. Collocation: Definition and Classification}

Scholars have defined the term collocation in a various but seemingly similar way. McCarthy and O'Dell (2005) define collocation as a close word combination with other words as in the following examples: too collocates with much or late; the word tall seems to collocate with building and high with mountain. Lewis (2000) gives the meaning of collocation as the method of unexpected natural co-occurrence with lexical items in a context. Oxford Collocations Dictionary for Students of English (McIntosh, Francis, \& Poole (2009) offers the following clear-cut definition "Collocation is the way words combine in a language to produce natural-sounding speech and writing (p. v). It elaborates further by providing examples such as strong wind, and heavy rain.

Pertaining to the classification of collocations, various types of collocations have been distinguished. However, Benson, Benson, and Ilson (2010) seem to be the first academics who delineate the two major strands of collocations which have been widely well-accepted -Grammatical collocations and lexical collocations.

Grammatical collocations consist of the main word (a noun, an adjective, a verb followed by a preposition or 'to+infinitive' or 'that-clause' and they are marked by 8 basic sub-categories:

$\mathrm{G} 1=$ noun + preposition e.g. blockade against, apathy towards

$\mathrm{G} 2=$ noun + to-infinitive e.g. He was a fool to do it., They felt a need to do it.

$\mathrm{G} 3=$ noun + that-clause e.g. We reached an agreement that she would represent us in court., He took an oath that he would do his duty.

G4= preposition + noun e.g. by accident, in agony

G5= adjective + preposition e.g. fond of children, hungry for news

$\mathrm{G6}=$ adjective + to-infinitive e.g. it was necessary to work, it's nice to be here

$\mathrm{G} 7=$ adjective + that-clause e.g. she was afraid that she would fail, it was imperative that I be here

G8= 19 different verb patterns in English e.g. verb + to-infinitive (they began to speak), verb + bare infinitive (we must work) and other.

Lexical collocations consist of two or more content words, i.e. nouns, verbs, adjectives, and adverbs. They do not contain prepositions, infinitives or relative clauses. Examples of lexical collocations as follows:

$\begin{array}{ll}\text { Adjective + noun } & : \text { sour milk } \\ \text { verb + noun } & : \text { conduct research } \\ \text { noun + noun } & : \text { dust accumulates } \\ \text { adverb + adjective } & : \text { mentally disabled } \\ \text { verb + adverb } & : \text { move freely } \\ \text { adverb + verb } & : \text { proudly present }\end{array}$

However, Wei's (1999 as cited in Tekingul, 2013)) classification of collocations is still practical and seems to add to the seemingly incomplete list. He added one more category to collocations; that is, idiomatic expressions. Idiomatic expressions are the combinations of words that are entirely fixed, and it is impossible to substitute any of their components with other words.

Examples of idiomatic expressions include: kick the bucket, till the cows come home, it rains cats and dogs, wet behind the ears, in conclusion, a helping hand, etc. For the purpose of the present study, Wei's classification of collocations was applied.

\section{B. Importance of Collocations}

The literature in reference to the importance of collocational knowledge or competence seems to have agreed on the three common areas of the importance of collocations for language competence. First, language knowledge requires collocational knowledge. As claimed by Hill (2000), collocations are everywhere. They are found in up to $70 \%$ of everything said, heard, read, or written. Collocations underline the strong patterning that exists in language and shows that a word-by-word approach cannot be an effective way of deriving the meaning in a text. Moreover, Nation (2001) posits that the strongest stance is that language knowledge is collocational knowledge because "the stored sequences of words are the bases of learning, knowledge and use" (p. 321).

The next importance of collocational knowledge lies in the fact that it is key to native-like production (Men, 2018); that is to say, a good command of collocational knowledge helps to achieve the native-like production through promoting fluency. What differentiates between native speakers and non-native speakers is that native speakers have accrued more examples of the language and are consequently able to speak at a relatively fast pace because of their calling on a vast repertoire of ready-made language in their long-term memory (Hill, 1999). That L2 learners can use language fluently indicates their native-like fluency. When L2 learners communicate in the target language, they usually compose sentences by putting words together. This process delays their speech. Some English learners spend a bit longer time thinking about what words to say and when they speak, they speak in a broken manner because they try to 
choose words for use together. If they know collocations, they will speak faster because of the word combinations in their mental lexicon will work automatically, thus there is no waste of processing time, which usually renders a mistake.

Another salient benefit of knowing collocations is it contributes to efficient comprehension for L2 learners. Hunston and Francis (2000) maintains that with a good command of collocational knowledge, learners can understand the meaning of text without having to focus on every single word. Fluency in reading and listening can also be enhanced as a result of this knowledge. L2 learners can reconstruct the meanings even if they mishear some words in speech. Collocation is thus recognized by Lewis (2000) as "the most powerful force in the creation and comprehension of all naturally-occurring texts" (p.45).

\section{Development of Collocational Competence}

It has been widely accepted that collocational competence can be developed through systematic and explicit teaching methods. Dokchandra (2015a) systematically taught Thai EFL students how to notice collocations as they read 4 English texts from the VOA news special English web pages and 4 texts from BBC learning English web pages. After 8 weeks of instruction, it was found that the experimental group's collocation test score significantly increased from before the treatment, and the researcher confirmed that teaching collocation noticing in a systematic way indeed helped to develop the learners' collocational competence, particularly their receptive skill of colocations. Other researchers, moreover, confirmed similar results of a systematic instruction of collocations for learners' improved writing abilities (Eidian, Gorjian, \& Aghvami, 2014), as well as speaking abilities (Attar, 2013; Mohammadi \& Enayati, 2018).

\section{Relevant Past Studies}

Several studies have been carried out to investigate collocational competence of Thai learners of English, especially at the university level. Mallikamas \& Pongpairoj (2005) investigated the collocational knowledge of Thai learners of English in the receptive and productive modes, and found that lexical collocations and grammatical collocations were equally difficult for them to receive. In the productive mode, lexical and bound collocations were found to be less difficult. Other research works focused on some patterns of collocations as the objectives of investigation. For example, Detdamrongpreecha (2014) singled out three patterns of lexical collocations for the investigation; that is, verb+noun, adjective+noun, and noun+noun, in order to investigate the receptive and productive collocational knowledge of the students-International programme, English major, and non-Engish major. On the whole the results indicated that the students of all groups had fair level of collocational competence. The findings indicated that the participants could identify which were nouns, adjectives or verbs, but they did not know how to use those words in collocations. The researcher put this down to the fact that collocations are rarely taught, even if they are, the learners do not pay sufficient attention. Suwitchanphan and Phoocharoensil (2014) also measured the collocational competence of Thai EFL students focusing on the adjective + noun pattern of lexical collocations. The participants were regular programme and English programme secondary school students, and they were administered three formats of collocation test-gap-filling, multiple-choice selection, and descriptive written task. The findings showed that the regular programme students outperformed the English programme students, whose medium of instruction is English, rendering the author to justify that massive exposure to the target language without sufficient opportunity to produce adjective+noun collocations through speaking and writing in class is not necessarily conducive to enhancement of adjective+noun collocational competence. This finding was reiterated by El-Dakhs (2015) who studied the collocational competence of 90 Arab undergraduate students at three academic levels in a university in Saudi Arabia, and found that collocational competence of learners was notably unsatisfactory though English is the medium of instruction at the university. Recent research by Thongviti and Thumwongsa (2017) who investigated the misused collocations in research article abstracts written by Thai EFL writers indicated the difficulty of grammatical collocation (noun+preposition) followed by lexical collocation (adjective+noun).

The above-reviewed line of research seems to focus on the two popular classifications of grammatical and lexical collocations, but the idiomatic expressions as another category of collocations are rarely researched. Previous research is therefore still shallow pertaining to the exact types of collocations that pose the real problems for EFL learners. Moreover, no research has been done to investigate the collocational difficulty as perceived by EFL learners in parallel with their collocational competence. To fill this gap, the present study was carried out.

\section{Methodology}

\section{A. Population and Sampling}

Two hundred and twenty seven second, third, and forth year-students of English who enrolled in the second term of the academic year 2017 at Sakon Nakhon province campus of Kasetsart University in Thailand's northeastern province of Sakon Nakhon served as the population of this research. Of the 227 students, 153 were conveniently selected as the samples on the basis of their willingness to take part in the study. Subsequently, the samples were administered the collocational test and the collocational difficulty questionnaire.

\section{B. Research Instrument}

Collocational Competence Test and Collocational Difficulty Questionnaire (CCT\&CDQ) 
The CCT\&CDQ was an all-inclusive data collection tool the researcher constructed for gathering the data pertaining to both the collocational competence of the participants and their perceptions of collocational difficulty.

The CCT\&CDQ was composed of two parts: Part I was a demographic section which contains 4 items that elicit personal information about the participants in terms of age, gender, year of study, and the recent GPA. Part II was a 35item set of a collocational competence test and a collocational difficulty questionnaire. Each item is an English sentence with a blank where one correct collocate is needed to be chosen in order to form the correct collocation. The participants had to choose one best alternative out of the three given in the parenthesis by underlining or circling it). At the same time, they were required to rate the difficulty of each target collocation by indicating the level of difficulty ranging from " $5=$ Very difficult", "4 = Fairly difficult", "3= Difficult", "2= Easy", and "1= Very easy". Of the 35 items in the CCT\&CDQ, 12 items (item 1-12) were grammatical collocations; 18 items (item 13-30) were lexical collocations; and 5 items (item 31-35) were idiomatic expressions. There was an indication of the collocation type prior to each group of the test items. Figure 1 below illustrates what each test item looks like.

\begin{tabular}{|l|l|l|l|l|l|l|}
\hline & \multicolumn{1}{|l|}{} & 5 & 4 & 3 & 2 & 1 \\
\hline 0 & $\begin{array}{l}\text { Noun + Verb } \\
\text { Business is for the big car companies. } \\
\text { booming/ advancing / progressing ) }\end{array}$ & & & & & \\
\hline
\end{tabular}

Figure 1: An example of a CCT\&CDQ item

In this example, the word booming is to be chosen as the correct collocate, indicating that "Business is booming" is the correct collocation (Noun + Verb), while "3" is chosen to indicate that the respondent considers this collocation as somewhat difficult. In order to ensure the reliability of the research tool, the internal consistency method was implemented in this study which involved one test, one research tool, and one group of participants. The CCT\&CDQ was tried out in two stages, in the first pilot stage and in the second one. The piloted version of the CCT\&CDQ was administered to 15 students of English who were not the same target group (year 2-4) at Sakon Nakhon Rajabhat University, and the Cronbach's alpha coefficient of the tool was 0.791. The CCT\&CDQ was then slightly amended and improved before being put to use with another group of 30 English major students at the same university. The improvement of the CCT \& CDQ included, for example, changes of some words in each sentence to ensure they were in the list of high frequency words, and the layout of the questionnaire as a whole. This is because some respondents commented that the CCT\&CDQ looked a bit crammed. Also, from the researcher's own observation, they students seemed to be in a rush in completing the CCT\&CDQ, and that might have resulted from their tiredness from reading the poorly-designed layout of the test and questionnaire. The results of the second piloted study saw the CCT\&CDQ reach a Conbrach's alpha of 0.96 , hence being deemed highly reliable and acceptable for use in this study. Generally, a Cronbach's alpha of .70 and above is fair, .80 and above is good, and .90 and above is excellent (Taylor, 2013).

\section{Procedure}

The researcher and his assistants started collecting the data by administering the CCT\&CDQ to the participants in August, 2017. To this end, they sought cooperation from the teachers who taught the class which was attended by the participants in making sure the they took it seriously in completing the CCT\&CDQ; that is, they were not allowed to use a dictionary of any type, and collecting the completed CCT\&CDQ, which was then handed over to the researcher and his assistants.

\section{Coding, Scoring, and Analyzing the Data}

The collocational competence test in the CCT\&CDQ was then coded and scored by using the answer key prepared by the researcher based on Oxford Collocations Dictionary for Students of English (McIntosh, Francis, \& Poole (2009) and BBI Combinatory Dictionary of English (Benson, Benson, \& Ilson, 2010). In addition, an English native teacher was requested to give a helping hand in crosschecking and confirming that the word chosen as the correct choice in each item can no longer collocate with other words. The right answer received " 1 " and the wrong answer received "0". An unanswered item was given "0" as well. The researcher used SPSS for Windows (version 21) to analyze the data for descriptive statistics-percentage, mean, and standard deviation, and statistical tests -independent samples t-test, correlation, and one-way ANOVA.

\section{RESULTS}

\section{A. The Participants' Demographic Results}

One hundred and fifty three students took part in this study. Of this number, there were 77 second-year students (50.3\%), $36(23.5 \%)$ third-year, and 40(26.1\%) fourth-year students, respectively. In terms of the level of English proficiency, 29 students (19\%) were low, 108 students (70\%) medium, and 16 students (10.5\%) were high.

\section{B. Answer to Research Question 1}


To answer research question 1 which asks: "What is, holistically, the collocational competence of the students of English at KUCSC?", the collocational competence test (CCT) scores were computed. The participants' collocational competence was categorized into four levels based on the mean scores they managed to get: very low (0-7 scores), low (8-14 scores), moderate (15-21 scores), high (22-28 scores), and very high (29-35 scores).

As indicated in Table 1, the average collocational competence test (CCT) score of 153 participants was only 16 (44\%) out of total score of 35. This indicates that the students of English at KUCSC had a moderate level of English collocational competence. Taking into account the 15.56 mean, which is just 1.56 higher than 14 , it can be seen that the participants' collocational competence was only narrowly higher than the low level. The minimum score was 4 , while the maximum score was 23.

TABLE I.

DESCRIPTIVE STATISTICS OF THE PARTICIPANTS' CCT SCORES

\begin{tabular}{|c|c|c|c|c|c|}
\hline Number & Min & Max & Mean & SD & Meaning \\
\hline 153 & 4 & 23 & 15.56 & 3.02 & Moderate \\
\hline
\end{tabular}

The participants' overall collocational competence by types

As illustrated in Table 2, the students had a very low level of competence in idiomatic expressions, while with regard to grammatical and lexical collocations, they had a low level of competence. Only 8 out of 18 items of lexical collocations $(43.61 \%)$ were correctly answered by the students, and only half of the students $(51.16 \%)$ could correctly select the grammatical collocation items.

In detail, there were 12 items of grammatical collocations. On average, only $78(60.70 \%)$ students could correctly answer this part of the test items, while 75 students $(46.42 \%)$ chose the wrong answers.

The idiomatic expressions part of the CCT contained 5 items. Of the 153 students, only 49 (32\%) correctly answered these 5 test items. Most of them (68\%) chose the wrong answers. On the whole, it was found that there was only one item (item 31- He was caught between the devil and the deep .(blue sea, green line, hole) that was correctly chosen by more than half of the students. The items other than item 31 were wrongly answered by more than half of the students.

TABLE II.

PARTICIPANTS' COLLOCATIONAL COMPETENCE By TYPES $(\mathrm{N}=153)$

\begin{tabular}{ccccccc}
\hline Types of collocations & Min & Max & $\begin{array}{c}\text { Total } \\
\text { Score }\end{array}$ & Mean & S.D. & Percent \\
\hline Grammatical collocations & 2 & 11 & 12 & 6.14 & 1.76 & 51.16 \\
Lexical collocations & 0 & 12 & 18 & 7.85 & 1.86 & 43.61 \\
Idiomatic expressions & 0 & 4 & 5 & 1.61 & 1.10 & 32.2 \\
\hline
\end{tabular}

\section{Answer to Research Question 2}

Are the second, third, and fourth-year students significantly different in terms of their competence in grammatical collocations, lexical collocations, and idiomatic expressions? As illustrated in Table 3, the average mean scores of the students classified by their years of study look seemingly not much different. However, one-way ANOVA (F-test) was used to analyze the results to assess the differences in the collocational competence among the second, third, and fourthyear students of English at KUCSC. The analysis showed statistical significance at the 0.05 level, as indicated in Table 4.

TABLE III.

PARTICIPANTS' COLlocational COMPETENCE Classified By YeAR OF STUDY (N=153)

\begin{tabular}{|c|c|c|c|c|c|c|}
\hline Year of study & Number & \multicolumn{2}{|c|}{ Minimum } & Maximum & Mean & SD \\
\hline 2 & 77 & \multicolumn{2}{|c|}{4} & 21 & 14.87 & 3.10 \\
\hline 3 & 36 & \multicolumn{2}{|c|}{12} & 22 & 16.83 & 2.53 \\
\hline 4 & 40 & \multicolumn{2}{|c|}{11} & 23 & 15.75 & 2.91 \\
\hline \multicolumn{7}{|c|}{$\begin{array}{c}\text { TABlE IV. } \\
\text { F-TEST RESUlts For THE DIFFERENCES OF COLLOCATIONAL COMPETENCE BY YEAR OF STUDY }\end{array}$} \\
\hline & & ares & $\mathrm{df}$ & Mean Square & $\mathrm{F}$ & Sig. \\
\hline Between Groups & & & 2 & 44.780 & 5.078 & .007 \\
\hline Within Groups & & & 150 & 8.818 & & \\
\hline Total & & & 152 & & & \\
\hline
\end{tabular}

As shown in Table 4, the P-value (Sig.=.007) is smaller than the alpha value (0.05), the conclusion was that the second, third, and fourth-year students of English at KUCSC were significantly different in regard to their collocational competence at the 0.05 level.

\section{Answer to Researcher Question 3}

To answer the question: "Is there a significant difference in collocational competence among the students with different English proficiency levels?", the scores from the CCT were analyzed and it was found that, based on their 
recent grades point average, the high scorers $(\mathrm{GPA}=3.50-4.00)$ had the average CCT score of 16 , while the medium scorers (GPA $=2.50-3.49)$ got 15.50 on average, and the low scorers (GPA $=1.00-2.49)$ obtained 15.48 on average. To test if the students of three different proficiency levels are significantly different in terms of their collocational competence, F-test was conducted and the results of the analysis were as shown in Table 5.

TABLE V.

\begin{tabular}{cccccc}
\multicolumn{6}{c}{ F-TEST RESUlTS FOR THE COLLOCATIONAL COMPETENCE BY PROFICIENCY LEVELS } \\
\hline & Sum of Squares & df & Mean Square & F & Sig. \\
\hline Between Groups & 3.610 & 2 & 1.805 & .192 & .825 \\
Within Groups & 1408.639 & 150 & 9.391 & & \\
Total & 1412.248 & 152 & & & \\
\hline
\end{tabular}

As Table 5 indicates, the P-value $(\mathrm{Sig} .=.825)$ is larger than the alpha value $(0.05)$, it was therefore concluded that the students of English at KUCSC with different English proficiency levels were not significantly different in regard to their collocational competence.

\section{E. Answer to Research Question 4}

To find the answer to the question: "How do the students of English at KUCSC perceive collocational difficulty?", the data from the collocation difficulty questionnaire (CDQ) were analyzed for means and standard deviations, and the participant's perceptions of collocation difficulty were interpreted based on the following criteria for the interpretation of means: mean range from 4.21-5.00 = very difficult; $3.41-4.20=$ difficult; $2.61-3.40=$ Fairly difficult; $1.81-2.60=$ easy; $1.00-1.80$ = very easy.

The results of the data analysis showed that that the overall mean of the CDQ was 3.32, meaning "difficult", and the SD 0.74 indicated that the students of English at KUCSC perceived the collocation difficulty in the same direction; that is, they regarded collocation as something difficult.

To further investigate how the participants perceived the collocation difficulty according to types, the CDQ data were analyzed for the overall means and standard deviations of the perceptions of the difficulty of grammatical, lexical, and idiomatic expressions collocations.

TABLE VI.

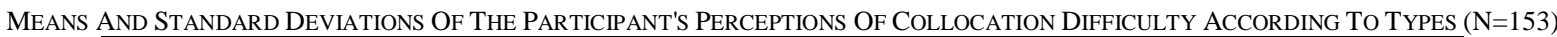

\begin{tabular}{lccc}
\hline Types of collocation & Mean & SD & Meaning \\
\hline Grammatical & 3.12 & 0.82 & Fairly difficult \\
Lexical & 3.35 & 0.81 & Fairly difficult \\
Idiomatic expressions & 3.69 & 0.91 & Difficult \\
\hline
\end{tabular}

Based on the results in Table 6, it was found that the participants perceived grammatical and lexical collocations as somewhat difficult, but the idiomatic expressions collocation was perceived as difficult.

The analysis of the CDQ also revealed the results regarding the participants' perceptions of collocation difficulty as subcategorized by their year of study and collocation types, as indicated in Table 7.

TABLE VII.

Means And Sd Of The Participant's Perceptions Of Collocation Difficult According To YeAR Of Study And Collocation Type $(\mathrm{N}=153)$

\begin{tabular}{lllll}
\hline Year of study / Type & Number & Mean & SD & Meaning \\
\hline 2 / Grammatical collocations & 77 & 3.35 & 0.87 & Fairly difficult \\
2 / Lexical collocations & 77 & 3.54 & 0.88 & Difficult \\
2 / Idiomatic expressions & 77 & $\mathbf{3 . 7 5}$ & 0.96 & Difficult \\
3 / Grammatical collocations & 36 & 2.90 & 0.47 & Fairly difficult \\
3 / Lexical collocations & 36 & 3.40 & 0.69 & Fairly difficult \\
3 / Idiomatic expressions & 36 & $\mathbf{3 . 8 2}$ & 0.90 & Difficult \\
4 / Grammatical collocations & 40 & 2.86 & 0.83 & Fairly difficult \\
4 / Lexical collocations & 40 & 2.93 & 0.60 & Fairly difficult \\
4 / Idiomatic expressions & 40 & $\mathbf{3 . 4 8}$ & 0.76 & Difficult \\
\hline
\end{tabular}

From Table 7, it can be clearly seen that the participants of all years of study perceived idiomatic expressions as difficult. Grammatical collocations and lexical collocations were perceived as somewhat difficult, with the exception that the second-year students also perceived lexical collocations as difficult.

\section{F. Answer to Research Question 5}

Question 5 asks: "Is there a significant difference in the perceptions of collocational difficulty among the second, third, and fourth-year students of English at KUCSC?" One-way ANOVA was computed to compare the means of the participants' perceptions of collocational difficulty, and the F-test results revealed that there was a significant difference $(\mathrm{F}=7.177, \mathrm{df}=2$, sig. $=0.001)$ in the perceptions of the difficulty of collocations among the second, third, and fourthyear students. To find out which groups of the participants are really different, a second Scheffe post hoc test was run, and the results are presented in Table 7. 
TABLE VIII.

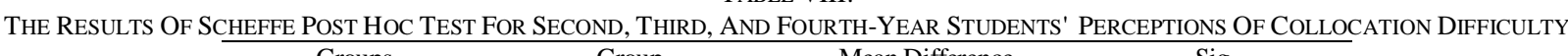

\begin{tabular}{cccc}
\hline Groups & Group & Mean Difference & Sig. \\
& & & .328 \\
& year3 & .21559 & .001 \\
\hline \multirow{2}{*}{ year2 } & year4 & $.52448^{*}$ & .328 \\
& year2 & -.21559 & .172 \\
\hline \multirow{2}{*}{ year3 } & year4 & .30889 & .001 \\
& year2 & $-.52448^{*}$ & .172 \\
\hline \multirow{2}{*}{ year4 } & year3 & -.30889 & \\
& & & \\
\hline
\end{tabular}

Table 8 shows that the differences in the perceptions of collocation difficulty among the three groups of students were significant. In other words, the second-year students perceived lexical collocations as difficult, while the fourthyear students perceived the same type of collocations as somewhat difficult.

\section{DISCUSSION}

The overall results in this study indicated that the students had moderate to low level of collocational competence. The findings were in line with previous studies conducted in both Thailand and other countries which similarly confirmed that learners of English at all proficiency levels had difficulty learning and using English collocations (Hsu \& Chiu, 2008; Yumanee \& Phoocharoensil, 2013). In particular, the findings in this study reflected the conclusion by Mallikamas and Pongpairoj (2005) who asserted that Thai learners of English had a considerable problem with lack of collocational knowledge which was a widespread problem.

The idiomatic expressions collocation was found to be the most difficult type as indicated by the students' CCT mean scores, followed by lexical collocations, and grammatical collocations respectively. The students also perceived this type of collocations as difficult. However, Yumanee and Phoocharoensil (2013) found that among Thai EFL learners with low proficiency level, lexical collocations were the most problematic to them. Idiomatic expressions collocations were not included in the classification of collocations in Yumanee and Phoocharoensil's study, and therefore, the findings in the present study added to the literature pertaining to Thai university EFL students' knowledge of collocations in the sense that the most problematic collocations for them were idiomatic expressions but not lexical or grammatical collocations. Moreover, the perceptions of collocational difficulty were found to be agreeable among all proficiency level groups.

Yumanee and Phoocharoensil (2013), investigating the receptive and productive knowledge of English collocations of high-proficiency group and low-proficiency group of Thai EFL students, found that both groups were of low levels of collocational knowledge. Both low and high achievers could not choose the correct lexical collocation of การจราจรหนาแน่น. The majority of the students chose "thick traffic" rather than "heavy traffic". By the same token, the incorrect choice of Verb + Noun lexical collocation was also found when they chose "compare a contrast" instead of "draw a contrast", while indicating in the CDQ (Item 29) that it was fairly difficult. Therefore, the conclusion can be drawn at this point that the students' collocational competence and their perceptions of collocational difficulty were consistent, based on their overall CCT scores in comparison with the perceptions of collocational difficulty they reported in the CDQ. That is to say, most of the students wrongly answered items 31-35 (Idiomatic expressions collocations), and at the same time, they perceived these items as difficult and very difficult.

The plausible explanations for the students' nearly low level of collocational competence could be due to their shortage of collocational knowledge (Hashemi, Azizinezhad, \& Dravishi, 2012), lack of a systematic teaching of collocations in class (Bueraheng, 2014 as cited in Chansopha, 2018), lack of support strategies for acquiring collocations (Dokchandra, 2015a), and less exposure time (Durrant \& Schmitt, 2010; Vahabian, et al. 2018). Collocational knowledge is important for language reception and production. With profound and rigid knowledge of collocations, EFL/ESL learners can expect to achieve the native-like language use target. The students in this study lacked collocational knowledge, thus clearly showcasing their failure in receiving and producing the target language as indicated in their CCT scores. In terms of the receptive skill, if the learners are struggling in the word combinations (another phrase for collocations), they will perform unsatisfactorily in any standard English tests, let alone the specific collocational test such as the one used in this study.

Several of the students in this study, in conversation with the author, revealed that they were not taught about collocations in high school, and also in other classes at the university, the teachers did not emphasize the importance of collocations. Unsystematic teaching of vocabulary is, for example, when the teachers tend to focus on individual words and often lack useful materials for raising learners' awareness of collocations (Henriksen, 2009). This lack of systematic teaching of collocations resulted in their low level knowledge of collocations and perceptions of the word combinations as difficult in this study. According to Dokchandra (2015b) and other scholars such as Rahimi and Momeni (2012), learners of English need to know and use specific strategies to support their acquisition of vocabulary, especially collocations. He proposes the four-element cycle of vocabulary acquisition-noticing, recording, revisiting, recreatingas a seemingly effective support strategy for learning and acquiring collocations. The four elements are in fact intertwined, and would be highly effective if EFL learners put them into use persistently. However, the salient fact in the present context of English learning and teaching in Thailand is that a vast number of learners do not uphold 
effective support strategies for learning collocations, their collocational competence development is, as a result, thwarted.

Less time exposure to collocations also accounts for the poor collocational knowledge of EFL learners. The participants in this study performed quite poorly in the CCT test, clearly indicating their lack of adequate exposure time to collocations. In this regard, Durrant and Schmitt (2010) posit that adequate input is highly important for the learners' retention of any learned collocations. Though learners are taught collocations in a systematic way, they are prone to the loss of retention of those word combinations if they do not consistently expose themselves to those collocations in an adequate input.

Lastly, the students' perceptions of collocational difficulty were in congruence with their almost low level of collocational competence; that is to say, they scored scantly from the CCT test, indicating that their perceptions were accurate. Several participants in this study indicated that idiomatic expressions were not difficult, but on the whole, their CCT performance was less than satisfactory. One explanation in this regard could be that learners may know idioms, but they are often wanting in the knowledge of when or how the idioms can be used appropriately (CelceMurcia \& Larsen-Freeman, 1998; Siyanova \& Schmitt, 2007). Another explanation might be that those students were not determined enough in answering the test. They just selected the alternatives and indicated their perceptions of the difficulty of the test item at their whim. For example, they perceived item 13 of the CCT\&CDQ [She was an adviser the prime minister. (of, to, for)] as easy, but in fact they wrongly scored because of their selection of "of" instead of "to". This wrong perception and consequently, wrong answer could be attributed to first language interference. The phrase adviser to is equivalent to ที่ปรึกษาของ in Thai, and the preposition ของ is generally translated as of, hence incorrect collocation when she was an adviser of the prime minister was chosen.

\section{RECOMMENDATIONS}

\section{A. Pedagogical Recommendations}

(1) EFL learners should be systematically taught to be aware of and notice collocations in use (Ghazali, 2015). In this regard, the teacher is of a substantial role to play in teaching the learners to habitually notice collocations as used in authentic English. Supplementary exercises and activities for enhancing the noticing of collocations could be drawn on from various authentic newspapers and other online materials. In practice, when teaching how to notice collocations, the teacher should emphasize the structures involved such as adjective + noun and adverb + adjective, etc.

(2) The length of time for practicing the noticing and using collocations should not be short (e.g. 1-2 months), rather lengthy periods of at least 1 year should be emphasized because even 4-6 months might not be sufficient for the noticeable enhancement of collocational development (Li \& Schmitt, 2010).

(3) More emphasis should be placed on idiomatic expressions when EFL learners are taught about collocations. To this end, the teacher should urge the learners to do more self-study on the idiomatic expressions that are mostly associative with basic vocabulary. For example, the word blow appears in the idiom blow the gaff, meaning lose one's temper or become angry and cannot stay calm.

\section{B. Recommendations for Future Research}

(1) Future research should be carried out to investigate the collocational competence of Thai EFL students as well as their perceptions of collocational difficulty on a larger scale, for example at a cross-country level in order to get the holistic picture of the Thai EFL learners' levels of collocational competence and perceptions.

(2) Future research should explore pedagogical methods that focus on the development of idiomatic expressions and their effects on the learners' improvement of idiomatic expressions.

(3) Since this research relied on a questionnaire as its major tool for exploring the participants' perceptions of collocational difficulty, future research might incorporate other data collection tools such as an in-depth interview in order to grasp broader and more extensive perceptions of the participants.

\section{REFERENCES}

[1] Attar, E.M. (2013). The effects of teaching lexical collocations on speaking ability of Iranian EFL learners. Theory and Practice in Language Studies, 3(6), 1070-1079. doi:10.4304/tpls.3.6.1070-1079.

[2] Benson, M., Benson, E. \& Ilson, R. (2010). The BBI dictionary of English word combinations (3rd ed.). Amsterdam: John Benjamins Publishing Co.

[3] Celce-Murcia, M., \& Larsen-Freeman, D. (1998). The grammar book: An ESL/EFL teacher's course (2nd ed.). Boston, MA: Heinle ELT

[4] Chansopha, N. (2018). The use of international business management collocations by Thai EFL speakers. LEARN Journal: Language Education and Acquisition Research Network Journal, 11(1), 87-109.

[5] Detdamrongpreecha, D. (2014). The acquisition of basic collocations by Thai learners of English. SDU Res.J. 10(3), $37-53$.

[6] Dokchandra, D. (2015a). The effects of collocation noticing instruction on Thai EFL learners' collocational competence. Journal of Advances in English Language Teaching, 3(1), 1-11. 
[7] Dokchandra, D. (2015b). The Lexical Approach: An emphasis on the cycle of vocabulary acquisition. https://www.researchgate.net/publication/280924556_The_Lexical_Approach_An_Emphasis_on_the_Cycle_of_Vocabulary_Acquisit ion (accessed 8/12/2018).

[8] Durrant, P. \& Schmitt, N. (2010). Adult learners' retention of collocations from exposure. Second Language Research, 26(2), 163-188.

[9] Eidian, F, Gorjian, B. \& Aghvami, F. (2014). The effect of lexical collocation awareness on Iranian EFL learners' writing skill. Academia Journal of Educational Research 2(1), 001-006.

[10] El-Dakhs, D.A.S. (2015). The lexical collocational competence of Arab undergraduate EFL learners. International Journal of English Linguistics, 5(5), 60-74.

[11] Ghazali, F.A. (2015). Reinforcing students' collocational competence in EFL classrooms. MJAL, 7(3), 1-18.

[12] Hashemi, M., Azizinezhad, M., \& Dravishi, S. (2012). Collocation a neglected aspect in teaching and learning EFL. Procedia_Social and Behavioral Sciences, 31, 522-525.

[13] Henriksen, B. (2009). Research on L2 learners' collocational competence and development. EUROSLA Monographs Series 2 : L2 vocabulary acquisition, knowledge and use, 29-56. https://doi.org/10.1016/j.sbspro.2011.12.013.

[14] Hill, J. (2000). Revising priorities: From grammatical failure to collocational success. In M. Lewis (Ed.), Teaching collocation: Further developments in the lexical approach. Hove: Language Teaching, 47-69.

[15] Hunston, S., \& Francis, G. (2000). Pattern grammar. A corpus-driven approach to the lexical grammar of English. Amsterdam: Benjamins.

[16] Lewis, M. (1997). Implementing the Lexical Approach. Hove: Language Teaching Publications.

[17] Lewis, M. (2000). Teaching collocation: Further developments in the lexical approach. London: Language Teaching Publications

[18] Li, J., \& Schmitt, N. (2010). The development of collocations use in academic texts by advanced L2 learners: a multiple case study approach. In D. Wood (Ed.), Perspectives on formulaic language: Acquisition and communication. London/New York: Continuum, 23-46.

[19] Mallikamas, P., \& Pongpairoj, N. (2005). Thai Learners' Knowledge of English Collocations. HKBU Papers in Applied Linguistic Studies, 9, 1-22.

[20] McCarthy, M., \& O’Dell, F. (2005). English collocations in use: how words work together for fluent and natural English. Self-study and classroom use. Cambridge: Cambridge University Press.

[21] McIntosh, C., Francis, B., \& Poole (Ed.) (2009). Oxford collocations dictionary for students of English (6th ed.). Cambridge: Cambridge University Press.

[22] Meechai, D. \& Chumworathayee, T. (2015). Verb+Noun collocational competence of Thai university EFL students: A comparative study of a regular program and an English program. Language Education and Acquisition Research Network (LEARN) Journal, 8(2), 145-160.

[23] Men, H. (2018). Vocabulary increase and collocation learning: A corpus-based cross-sectional study of Chinese learners of English. Singapore: Springer.

[24] Mohammadi, M. \& Enayati, B. (2018). The effects of lexical chunks teaching on EFL intermediate learners' speaking fluency. International Journal of Instruction, 11(3), 179-192.

[25] Mongkolchai, A. (2008). A study of university students' ability in using English collocations. Master's Thesis, Srinakharinwirot University.

[26] Nation, I.S.P. (2001). Learning vocabulary in another language. Cambridge: Cambridge University Press.

[27] Rad, Z.A. \& Saniei, A. (2016). The application of projected visuals in teaching collocations to intermediate EFL learners. Journal of Language Teaching and Research, 7(6), 1136-1141.

[28] Rahimi, M. \& Momeni, G. (2012). The effect of teaching collocations on English language proficiency. Procedia-Social and Behavioral Sciences, 31, 37-42.

[29] Siyanova, A., \& Schmitt, N. (2007). Native and nonnative use of multi-word vs. one-word verbs. International Review of Applied Linguistics, 45, 119-139.

[30] Sridhanyarat, K. (2018). Thai learners' acquisition of L2 collocations: An interlanguage perspective. GEMA Online Journal of Language Studies, 18(1), 1-21. http://doi.org/10.17576/gema-2018-1801-01.

[31] Taylor, J.J. (2013). Confusing stats terms explained: Internal consistence. http://www.statsmakemecry.com/smmctheblog/confusingstats-terms-explained-internal-consistency.html (accessed 9/12/2018).

[32] Tekingul, B. (2013). Collocation teaching effect on reading comprehension in advanced EFL setting. Procedia-Social and Behavioral Sciences, 70, 1078-1089.

[33] Thongvitit, S. \& Thumawongsa, N. (2017). A corpus-based study of English collocations found in the abstracts of research articles written by Thai EFL writers. International Journal of Social Science and Humanity, 7(12), 751-755. doi:10.18178/ijssh.2017.7.12.920

[34] Vahabian, M., Asghari, S.Z., Esna-Ashari, F., \& Laghab, H.M. (2018). Collocational competence level of medical English among Iranian Medical students. JAHR, 9(1), 9-24.

[35] Wei, Y. (1999). Teaching collocations for productive vocabulary development. Paper presented at the Annual Meeting of the Teachers of English to Speakers of Other Language. New York.

[36] Yumanee, C., \& Phoocharoensil, S. (2013). Analysis of collocational errors of Thai EFL students. LEARN Journal, 6(1), 88-98.

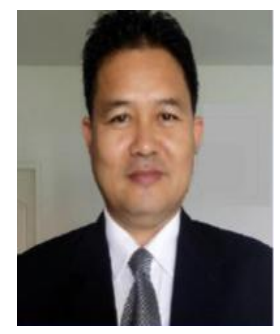

Dentisak Dokchandra is an assistant professor affiliated with the Department of Thai and Foreign Languages, Faculty of Liberal Arts and Management Science, Kasetsart University, Thailand. He holds a doctorate in English studies from Suranaree University of Technology, Nakhon Ratchasima, Thailand. His research interests cover the areas of second language (L2) reading and writing, language learning strategies, approaches to L2 learning and teaching, TEFL/TESOL, Computer Assisted Language Learning (CALL), and journalistic English. 